\title{
Karakteristik Bahan Bakar Padat Produk Torefaksi Limbah Tandan Kosong Kelapa Sawit Menggunakan Reaktor Torefaksi Kontinu Tipe Tubular
}

\author{
Retno Wahyudi ${ }^{*}$, Amrul $^{2}$, Muhammad Irsyad ${ }^{2}$ \\ ${ }^{1}$ Magister Teknik Mesin, Fakultas Teknik, Universitas Lampung \\ ${ }^{2}$ Teknik Mesin, Fakultas Teknik, Universitas Lampung \\ *e-mail: retnowahyudi92@gmail.com
}

\begin{abstract}
Abstrak - Cadangan minyak bumi semakin menipis, hal ini disebabkan meningkatnya ekonomi dan pertumbuhan penduduk sejalan dengan menigkatnya komsumsi energi. Selain itu juga disebabkan oleh meningkatnya jumlah kendaraan transportasi. Ketergantungan energi listrik dengan bahan bakar fosil, khususnya batubara di provinsi Lampung, dinilai masih cukup besar. Batubara sendiri diperkirakan dapat bertahan hingga 70 tahun mendatang, sementara cadangan batubara global diperkirakan akan habis sekitar 109 tahun kedepan dengan demikian diupayakan lebih intensif ke arah diversifikasi energi untuk mengurangi ketergantungan terhadap bahan bakar fosil, dan biomassa yang paling banyak dan berpotensi di Indonesia adalah kelapa sawit. Pada penelitian ini, kegiatan eksperimen melakukan pengujian produk limbah tandan kosong kelapa sawit yang dihasilkan oleh reaktor torefaksi kontinu tipe tubular menggunakan sistem pemanas oil jacket sebagai media torefaksi. Pengujian proksimat menunjukan bahwa semakin tinggi kandungan fixed carbon akan meningkatkan nilai kalor dari produk padatan hasil torefaksi, semakin meningkatnya temperatur pada proses torefaksi maka produk tandan kosong kelapa sawit semakin mempunyai emisi dan mempunyai sifat hydrophobic yang baik, nilai kalor produk padatan hasil torefaksi tandan kosong kelapa sawit berkisar antara $16357.23-21083.98 \mathrm{~kJ}$, setara dengan batubara subbituminous $\mathrm{C}$ yang memiliki nilai kalor sebesar $19300-2100 \mathrm{~kJ}$.
\end{abstract}

Kata Kunci : karakteristik bahan bakar padat, torefaksi, limbah kelapa sawit

\begin{abstract}
Petroleum reserves are running low, this is due to increased economic and population growth in line with rising energy consumption. It was also caused by an increasing number of transportation vehicles. The dependence of electricity with fossil fuels, especially coal in Lampung province, is still considered quite large. Coal itself is expected to last for the next $\mathbf{7 0}$ years, while global coal reserves are estimated to be depleted in the next 109 years and thus be pursued more intensively towards diversifying energy to reduce dependence on fossil fuels, and the most potential biomass in Indonesia is palm oil. In this study, the experimental activity tested the oil palm empty fruit bunch waste products produced by a continuous tubular reactor type tubular reactor using an oil jacket heating system as a torefaction media. Proximate testing shows that the higher the fixed carbon content will increase the calorific value of the solid product from the torefaction product, the increasing temperature in the torefaction process, the oil palm empty fruit bunch products will have more emissions and have good hydrophobic properties, the heating value of the solid product from the coconut empty fruit bunch oil palm ranges from $16357.23-21083.98 \mathrm{~kJ}$, equivalent to subbituminous $\mathrm{C}$ coal which has a calorific value of $19300-2100 \mathrm{~kJ}$.
\end{abstract}

Keywords : characteristics of solid fuels, torefaction, palm oil waste

This is an open access article distributed under the Creative Commons 4.0 Attribution License 


\section{Pendahuluan}

Indonesia merupakan salah satu negara yang memiliki jumlah penduduk terbesar ke empat di dunia. Berdasarkan Badan Pusat Statistik (BPS) pada tahun 2019 jumlah penduduk Indonesia mencapai 267 juta jiwa [4]. Dengan besarnya jumlah penduduk secara tidak langsung mempengaruhi kebutuhan energi terutama dalam sektor rumah tangga, transportasi dan pada sektor industri, dimana sebagian energi di suplai dari bahan bakar fosil [1-3].

Cadangan minyak bumi atau energi fosil khususnya minyak bumi semakin menipis. Ketergantungan negara-negara di dunia merupakan faktor utama semakin menipisnya cadangan minyak bumi. hal ini desebabkan meningkatnya ekonomi dan pertumbuhan penduduk sejalan dengan menigkatnya komsumsi energi, Selain itu juga disebabkan oleh meningkatnya jumlah kendaraan transportasi, dan semakin banyaknya pabrik/manufaktur yang menggunakan energi fosil, sehingga mengakibatkan cadangan minyak bumi semakin menipis $[6,9]$.

Ketergantungan energi listrik dengan bahan bakar fosil, khususnya batubara di provinsi Lampung, dinilai masih cukup besar, hal ini dibuktikan dengan provinsi Lampung yang memiliki lokasi strategis di Sumatera menurut (ESDM) Indonesia sendiri merupakan penghasil batubara terbesar nomor dua di dunia dengan kualitas yang baik [8]. Hal ini banyak ditemui pada perusahaan yang ada di Lampung, yang mengelola batu bara menjadi energi listrik, antara lain PT. Bukit Asam, dan PT. PLN, hal ini menjadikan provinsi Lampung masih sangat bergantung pada bahan bakar fosil, khususnya batu bara untuk pembangkit energi listrik [5,7].

Melihat tingkat produksi batubara yang mencapai 458 juta ton pada tahun 2014, dan apabila diasumsikan tidak ada peningkatan cadangan terbukti, maka batubara diperkirakan dapat bertahan hingga 70 tahun mendatang, sementara cadangan batubara global diperkirakan akan habis sekitar 109 tahun kedepan dengan demikian perlu diupayakan lebih intensif ke arah diversifikasi energi untuk mengurangi ketergantungan terhadap bahan bakar fosil, yaitu mencari bahan bakar alternatif pengganti bahan bakar fosil yang mudah diperoleh dengan harga murah, hemat sekaligus aman dan paling memungkinkan dikembangkan secara masal dalam waktu relatif singkat, melalui penerapan teknologi maupun peralatan relatif sederhana [8].
Terbatasnya sumber energi fosil menyebabkan perlunya pengembangan energi terbarukan dan konservasi energi yang disebut pengembangan energi hijau. Yang dimaksud dengan energi terbarukan di sini adalah energi non-fosil yang berasal dari alam dan dapat diperbaharui. Bila dikelola dengan baik, sumber daya itu tidak habis $[1,8]$.

Terkait dengan kebijakan penggunaan energi terbarukan pemerintah mengeluarkan Peraturan Pemerintah Nomor 79 tahun 2014, pada pasal 11 ayat 2, yang menjelaskan tentang prioritas pengembangan energi nasional yaitu memaksimalkan penggunaan energi terbarukan dengan memperhatikan tingkat keekonomian, meminimalkan penggunaan minyak bumi, memanfaatkan pemanfaatan gas bumi dan energi baru, menggunakan batu bara sebagai andalan pasokan energi nasional. Masih pada peraturan perintah nomor 79 tahun 2014 tentang kebijakan energi nasional tepatnya pada pasal 9 huruf $\mathrm{F}$ bahwasannya Indonesia mematok target pencapaian energi pada tahun 2025 peran energi baru dan energi terbarukan paling sedikit 23\% dan pada tahun 2050 paling sedikit $31 \%$ sepanjang keekonomian terpenuhi.

Salah satu bahan biomassa yang paling banyak dan berpotensi di Indonesia adalah kelapa sawit. Indonesia yang merupakan produsen dan eksporter terbesar minyak kelapa sawit (CPO) di dunia, dengan 14,03 juta hektar lahan perkebunan sawit dan memenuhi sekitar 37,8 juta ton atau $56,6 \%$ kebutuhan minyak kelapa sawit dunia pada tahun 2017, juga merupakan negara dengan potensi limbah biomassa sawit terbesar di dunia (ESDM, 2010). Limbah padat yang diperoleh dari pengolahan tandan sawit segar (TBS) meliputi tandan kosong (EFB) dengan persentase sekitar $23 \%$ berat TBS, abu boiler mencapai 0,5 $\%$ berat TBS, serat mencapai $12,5 \%$ berat TBS, dan cangkang yang mencapai 5,5\% berat TBS. Tandan kosong (TKKS) yang merupakan limbah padat dengan persentase terbesar masih belum banyak dimanfaatkan, kebanyakan hanya menjadi pupuk ataupun makanan ternak. Padahal dengan komponen selulosa 41,3-46,5\%, hemiselulosa 25,3-32,5 \% dan lignin 27,6-32,5 \%, TKKS memiliki potensi sebagai sumber energi yang cukup besar [7].

Teknologi yang saat ini sedang dikembangkan, dari sekian banyak teknologi yang tersedia untuk mengubah biomassa menjadi bahan bakar padat yang berkualitas adalah proses pirolisis pada temperatur relatif rendah yang dikenal dengan nama torefaksi (torrefaction). 
Dalam konteks bahan bakar, tujuan utama torefaksi adalah untuk menghasilkan produk berupa material padat dengan densitas energi yang tinggi. Temperatur yang digunakan pada proses torefaksi relatif rendah yaitu antara $200-$ $300{ }^{\circ} \mathrm{C}$ yang dilakukan pada tekanan atmosfir tanpa kehadiran oksigen, sehingga teknologi yang digunakan sederhana dan biaya investasi relatif rendah, namun mempunyai efisien konveersi energi yang tinggi, yakni hingga $90 \%$ [5].

\section{METODA}

Substansi dari penilitian ini adalah melakukan eksperimen terkait dengan limbah tandan kosong kelapa sawit yang kemudian dilakukan proses pembakaran melalui reaktor torefaksi tipe kontinyu, dimana hasil dari proses pembakaran dari produk torefaksi dilakukan pengujian laboraturium untuk mengetahui kandungan dan komposisi pada produk hasil torefaksi limbah tandan kosong kelapa sawit. Pengujian, meliputi, Persiapan eksperimetal set up, Mencacah limbah tandan kosong kelapa sawit sampai ukuran serabut, Pengujian tandan kosong kelapa sawit dengan variasi temperatur 200, 225, 250, 275, dan $300{ }^{\circ} \mathrm{C}$ dan waktu tinggal 30 menit dengan menggunakan torefaksi kontinu.

\section{A. Analisis proximate}

Analisis proximate dilaksanakan untuk mendapatkan data berupa karbon tetap (fixed carbon), moisture, zat volatile, dan kadar abu. Analisis nilai proximate dilaksanakan dengan menggunakan thermografimetric analyzer (TGA) mengikuti prosedur the JIS (Japan Industrial Standar) method. Pengamatan dengan menggunakan TGA dilaksanakan dengan menghitung perubahan berat sampel terhadap waktu dan temperature, yaitu moisture content (MC), volatile meter (VM), Fix carbon (FC), dan abu (ASH).

\section{B. Analisis ultimate}

Analisis ultimate dilaksankan untuk menganalisis nilai komponen yang terkandung didalam sampel bahan baku setelah torefaksi dilaksanakan untuk menghitung komponen kimia dilaksanakan dengan menggunakan instrument elemental analyzer. Komposisi elemen kimia atau nilai ultimate yaitu nilai carbon (C), hydrogen $(\mathrm{H})$, dan oksigen $(\mathrm{O})$, nitrogen $(\mathrm{N})$, dan sulfur $(\mathrm{S})$ yang didapatkan dari pengukuran selanjutnya digunakan untuk mencari nilai kalor HHV dan LHV, energy yield, mass yield, analisis Hydrophobic, analisis Torgas, analisis uji Pembakaran (emisi).

\section{HASIl Dan PeMbahasan}

Setelah dilakukan proses torefaksi dengan menggunakan reactor torefaksi kontinu tipe tubular di lab Thermodinamika Teknik Mesin Universitas Lampung, selanjutnya adalah melakukan pengujian sampel produk. Pengujian nilai proximate dan ultimate. Setelah dilakukan proses torefaksi dengan menggunakan reactor torefaksi kontinu tipe tubular di lab Thermodinamika Teknik Mesin Universitas Lampung, selanjutnya adalah melakukan pengujian sampel produk. Pengujian nilai proximate dan ultimate dilakukan di Laboratorium Teknik Kimia, Universitas Lampung.

Hasil uji proximate terhadap tandan kosong kelapa sawit menunjukan bahwa kandungan komponen tandan kosong kelapa sawit didominasi oleh volatile matter (VM) dan Fixed Carbon (FC). Komponen volatile matter (VM) berpengaruh terhadap nilai kalor hasil pembakaran, namun tidak sebesar nilai kalor yang dihasilkan oleh Fixed Carbon (FC). Semakin tinggi kandungan Fixed Carbon (FC) semakin meningkatkan nilai kalor bahan bakar. Kandungan FC tertinggi pada suhu $275^{\circ} \mathrm{C}$.

Proses tesebut menghasilkan 20,70\% dan terendah pada sampel mentah sebesar $10,80 \%$. Sedangkan fraksi massa zat volatile menurun dari $73,57 \%$ menjadi $61,40 \%$. Sedangkan pada kadar air atau Moisture Content (MC) nilai tertinggi terjadi tandan kosong kelapa sawit mentah yang belum dilakukan proses torefaksi. Pengujian sampel dengan temperatur proses torefaksi yang tinggi menyebabkan kandungan tinggi Fixed Carbon (FC) yang tinggi sebanding dengan kehilangan massa dan energi, namun menghasilkan densitas energi yang tinggi sehingga berpengaruh terhadap nilai kalor bahan bakar padat hasil torefaksi.

Hasil uji ultimate menunjukan bahwa konsentrasi atom berturut-turut adalah $\mathrm{C}>\mathrm{O}>\mathrm{H}$ $>\mathrm{N}>\mathrm{S}$. Kandungan kimia produk torefaksi dapta dilihat pada Gambar 4.2. Hasil pengujian meunjukan bahwa pengaruh kondisi operasi temperatur torefaksi terhadap kandungan atom dari limbah tandan kosong kelapa sawit sangat jelas terlihat. Sebagai contoh untuk kandungan 
carbon semakin tinggi tempratur sisa atom carbon semakin besar. Tandan kosong kelapa sawit sebelum ditorefaksi memiliki kandungan carbon sebesar $42,93 \%$, setelah dilakukan proses torefaksi naik hingga komposisinya mencapai $53,95 \%$ seiring dengan naiknya temperatur proses. Sebaliknya kandungan oksigen yang tersimpan pada biomassa mentah sebesar 49,350\% setelah dilakukan proses torefaksi diperoleh residu oksigen turun hingga $39,83 \%$. Seperi halnya dengan penurunan kandungan hidrogen dan sulfur. Kandungan unsur carbon sebanding dengan Nilai Kalor. Unsur $\mathrm{C}$ terdapat dalam fixed carbon dan volatile matter, sementara unsur $\mathrm{H}$ dan $\mathrm{O}$ berasal dari kandungan hidrokarbon dan air yang terdapat dalam produk torefaksi.

Tabel 1. Hasil pengujian

\begin{tabular}{ccccccccccc}
\hline Sampel & \multicolumn{3}{c}{ Analisis Proximate } & \multicolumn{3}{c}{ Analisis Ultimate } & \multicolumn{2}{c}{ Perbandingan } \\
& MC & VM & FC & Abu & C & H & N & O & O/C & H/C \\
\hline & $(\%)$ & $(\%)$ & $(\%)$ & $(\%)$ & $(\%)$ & $(\%)$ & $(\%)$ & $(\%)$ & $(\%)$ & $(\%)$ \\
\hline M & 11.63 & 73.57 & 10.80 & 4 & 42.93 & 5.56 & 2.16 & 49.35 & 1.15 & 1.55 \\
\hline A & 7.21 & 76.60 & 11.20 & 5 & 45.79 & 5.85 & 2.15 & 46.21 & 1.01 & 1.53 \\
\hline B & 7.10 & 73.80 & 12.10 & 7 & 46.60 & 6.09 & 1.33 & 45.98 & 0.99 & 1.57 \\
\hline C & 5.51 & 69.10 & 18.40 & 7 & 50.19 & 4.58 & 1.78 & 43.45 & 0.87 & 1.10 \\
\hline D & 6.33 & 65.97 & 20.70 & 7 & 52.78 & 5.89 & 1.58 & 39.75 & 0.75 & 1.34 \\
\hline E & 4.31 & 61.40 & 25.30 & 9 & 53.95 & 4.27 & 1.95 & 39.83 & 0.74 & 0.95 \\
\hline
\end{tabular}

Ketika temperatur torefakasi ditingkatkan dari $200^{\circ} \mathrm{C}$ menjadi $300^{\circ} \mathrm{C}$, hasil rasio molar $\mathrm{H} / \mathrm{C}$ menurun dengan konstan dari 1.57 ke 1.55, 1.53, 1.34, 1.10 dan 0,95. Pada rentang suhu yang sama, kandungan oksigen pada tandan kosong kelapa sawit produk torefaksi lebih sedikit dari tandan kosong kelapa sawit mentah, sehingga rasio $\mathrm{O} / \mathrm{C}$ biomassa tandan kosong kelapa sawit hasil torefaksi menurun. Rasio molar $\mathrm{O} / \mathrm{C}$ menurun dari 1.15 ke $1.01,0.99,0.87,0.75$ dan 0.74. Selama torefaksi, karena suhu meningkat, persentase berat konten $\mathrm{C}$ meningkat tetapi persentase berat $\mathrm{H}$ dan $\mathrm{O}$ menurun yang menjelaskan penurunan rasio $\mathrm{H} / \mathrm{C}$ dan $\mathrm{O} / \mathrm{C}$. Selain itu, rasio $\mathrm{O} / \mathrm{C}$ yang lebih rendah biasanya menguntungkan karena nilai kalor cenderung meningkat. Penurunan $\mathrm{O} / \mathrm{C}$ sekaligus $\mathrm{H} / \mathrm{C}$ ini akan meningkatkan kualitas bahan bakar. Peningkatan kualitas yang diperoleh cukup signifikan, dimana bahan bakar padat produk torefaksi tandan kosong kelapa sawit mendekati batubara. Bila diplot dalam diagram VanKrevelen, penurunan rasio $\mathrm{O} / \mathrm{C}$ dan sekaligus $\mathrm{H} / \mathrm{C}$ ini akan meningkatkan kualitas bahan bakar, seperti ditunjukan oleh Gambar 1.

Hal ini sesuai dengan teori yang mengatakan bahwa semakin kecil perbandingan $\mathrm{O} / \mathrm{C}$ dan $\mathrm{H} / \mathrm{C}$ maka intensitas energi yang terkandung dalam biomassa akan semakin besar. Selain itu dengan perbandingan $\mathrm{O} / \mathrm{C}$ dan $\mathrm{H} / \mathrm{C}$ yang lebih kecil dari biomassa yang tidak di torefaksi akan menyebabkan produk padatan hasil torefaksi memiliki nilai kalor per massa yang lebih tinggi, semakin kecil nilai $\mathrm{O} / \mathrm{C}$ maka biomassa dipastikan memiliki nilai kalor yang tinggi, begitu sebaliknya jika nilai $\mathrm{O} / \mathrm{C}$ besar maka nilai kalor yang terdapat pada biomassa kecil, sedangkan jika semakin kecil nilai $\mathrm{H} / \mathrm{C}$ maka biomassa memiliki sifat yang semakin lunak [2].

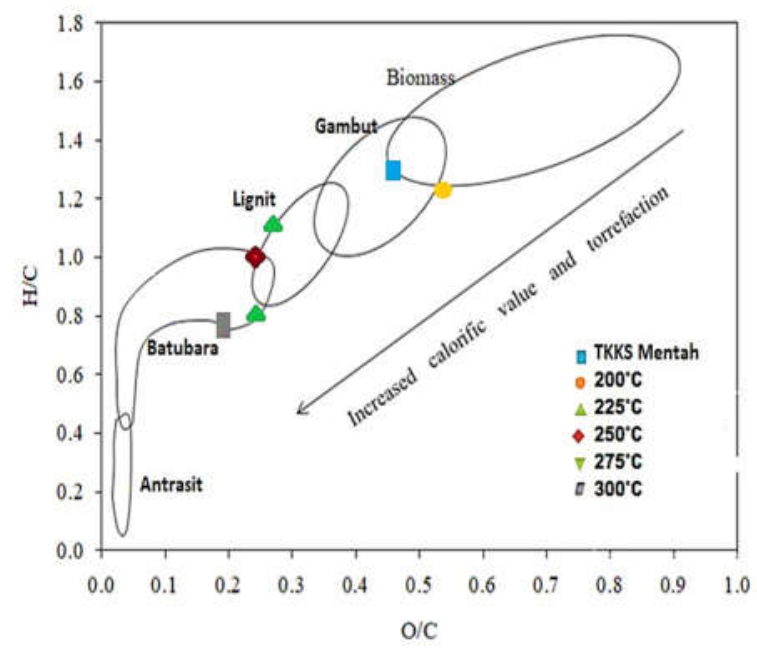

Gambar 1. Rasio O/C dan H/C

Pengujian nilai kalor pada penelitian ini dilakukan dengan mengolah data yang diperoleh dari hasil pengujian nilai proximate dan ultimate, 
nilai kalor kotor atau gross heating value atau lebih dikenal dengan higher heating value (HHV) dari sampel dapat ditentukan dengan menggunakan Persamaan:

$$
\begin{aligned}
& H H V=349.1 C+1178.3 H+100.5 S- \\
& 103.4 O-15.1 N-21.1 A S H \frac{k J}{k g}
\end{aligned}
$$

Nilai kalor bersih atau lower heating value (LHV) dari sampel dapat ditentukan dengan Persamaan

$$
H V=H H V-h_{g}\left(\frac{9 H-M}{100}\right)
$$

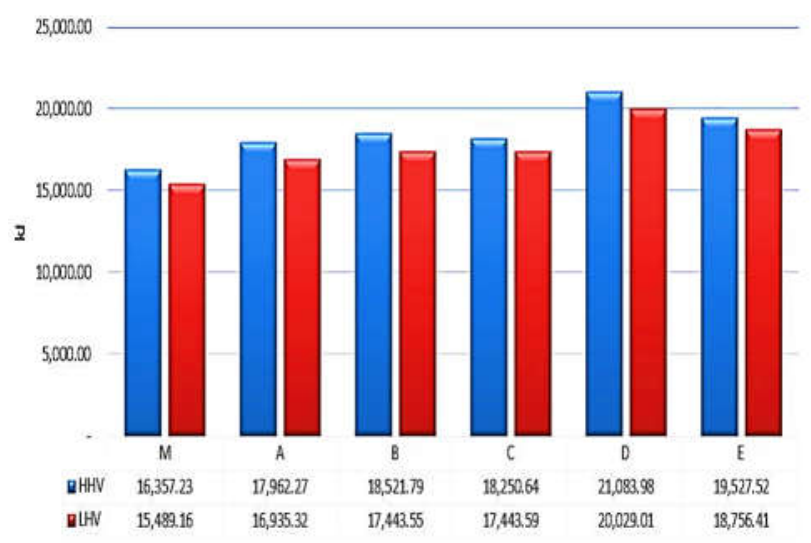

\section{Gambar 2. Nilai kalor HHV dan LHV}

Dari gambar 2 diketahui bahwa nilai HHV bahan bakar padat hasil torefaksi berkisar antara 16357,23 - 21083,98 kJ. Nilai HHV yang diperoleh dari hasil pengujian pada tandan kosong kelapa sawit sebelum torefaksi yaitu sebesar 16357,23 kJ dan nilai HHV produk tandan kosong kelapa sawit hasil torefaksi pada temperatur $200,225,250,275$ dan $300^{\circ} \mathrm{C}$ secara berturut - turut yaitu sebesar 17962,27 kJ, $18521,79 \mathrm{~kJ}, 18250,64 \mathrm{~kJ}, 21083,98 \mathrm{~kJ}$, dan 19527,52 kJ. Pada temperatur $275^{\circ} \mathrm{C}$ menghasilkan nilai HHV paling tinggi yaitu sebesar 21083,98 kJ sedangkan nilai HHV paling rendah didapatkan pada temperatur $200^{\circ} \mathrm{C}$ yaitu sebesar 17962,27 kJ. Nilai HHV yang didapatkan dari torefaksi tandan kosong kelapa sawit sesuai dengan teori yang ada pada umumnya, di mana dari temperatur rendah sampai temperatur di tingkatkan terjadi dekomposisi hemiselulosa dalam jumlah yang besar.

Dekomposisi yang terjadi pada fraksi hemiselulosa akan melepaskan uap air, gas $\mathrm{CO}$ dan $\mathrm{CO}_{2}$ serta zat terbang ringan yang memiliki nilai kalor rendah sehingga pada kedua temperatur tersebut terdapat selisih nilai kalor yang besar. Namun demikian, hasil pengujian nilai HHV tandan kosong kelapa sawit pada temperatur $300^{\circ} \mathrm{C}$ mengalami penurunan nilai HHV dari $275^{\circ} \mathrm{C}$, Padahal seharusnya dengan meningkatnya temperatur torefaksi akan menghasilkan nilai kalor yang semakin tinggi karena dengan meningkatnya temperatur proses torefaksi akan mempercepat dekomposisi pada biomassa $\mathrm{n}$ semakin banyak komponen organik yang terdekomposisi.

Umumnya biomassa memiliki kelemahan yaitu kemampuan menyerap air dari udara cukup tinggi sehingga biomassa bila disimpan di tempat terbuka akan memiliki kandungan air tinggi. Dengan kandungan air tinggi maka saat biomassa tandan kosong kelapa sawit dipergunakan sebagai bahan bakar akan menyulitkan dalam transportasi dan kehilangan energi pada saat dibakar. Hasil analisa kemampuan biomassa tandan kosong kelapa sawit menolak air dilakukan dengan mengambil sampel produk sebanyak 2 gram dan direndam di air selama 2 jam. Dari analisa limbah tandan kosong kelapa sawit yang telah dilakukan torefaksi, perubahan massa selama 2 jam perendaman terlihat bahwa kenaikan massa akibat menyerap air pada temperatur $200^{\circ} \mathrm{C}$ sebesar $0,22 \%$, pada temperatur 225 sebesar $0,17 \%$, pada temperatur 250 terjadi perubahan sebesar $0,13 \%$, pada temperatur 275 perubahan menjadi $0,10 \%$, dan pada temperatur 300 hanya $0,06 \%$.

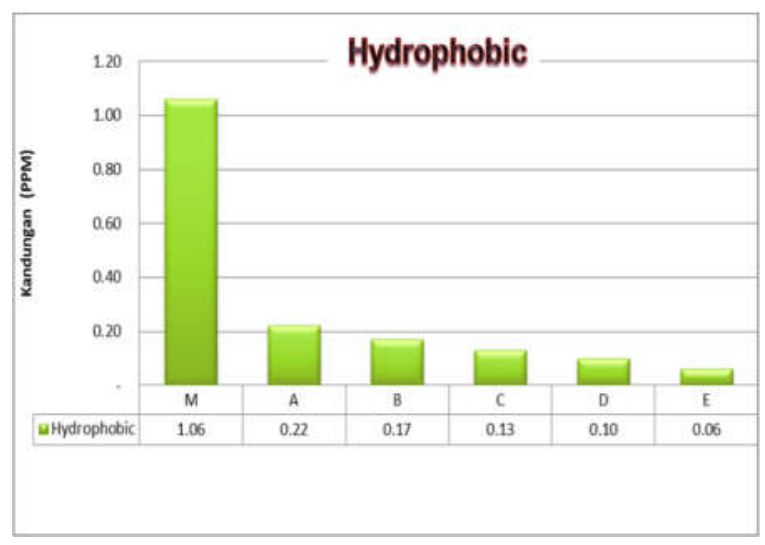

Gambar 4. Hydrophobia

Biomassa tanpa torefaksi dapat menyerap air hingga diatas $15 \%$ dan dinamakan sebagai air permukaan. Dengan demikian proses torefaksi dapat mengubah karakter biomassa tandan kosong kelapa sawit menjadi hidropobik. Dengan melihat ini bahwa torefaksi TKKS memiliki kenaikan air rendah dan meningkatkan daya hidropobik material [3]. Dari eksperimen torefaksi yang telah dilakukan dengan 
menggunakan reaktor torefaksi dan bahan baku limbah tandan kosong kelapa perolehan kandungan gas seperti di tunjukkan pada Tabel 2.

Tabel 2. Kandungan gas hasil torefaksi

\begin{tabular}{ccccc}
\hline Temperatur & $\begin{array}{c}\mathrm{CO}_{2} \\
(\%)\end{array}$ & $\begin{array}{r}\mathrm{CO} \\
(\%)\end{array}$ & $\begin{array}{c}\mathrm{CH}_{4} \\
(\%)\end{array}$ & $\begin{array}{c}\mathrm{H}_{2} \\
(\%)\end{array}$ \\
\hline A & 0.878 & 0.102 & 0.100 & 0.100 \\
B & 0.873 & 0.104 & 0.111 & 0.190 \\
C & 0.824 & 0.153 & 0.113 & 0.140 \\
D & 0.761 & 0.212 & 0.129 & 0.141 \\
E & 0.6972 & 0.251 & 0.278 & 0.232 \\
\hline
\end{tabular}

Hasil pengujian nilai Gas torefaksi tandan kosong kelapa sawit menunjukan bahwa kandungan komponen gas yang keluar saat proses torefaksi berlangsung didominasi oleh produk hasil torefaksi tandan kosong kelapa sawit pada temperatur tertinggi yaitu $300{ }^{\circ} \mathrm{C}$ dimana pada temperatur tersebut mendapatkan nilai gas CO terbesar yaitu $0,251 \%$, kemudian $\mathrm{CH}_{4}$ sebesar $0,278 \%$, dan nilai $\mathrm{H}_{2}$ sebesar 0,232 $\%$. Selanjutnya nilai perolehan Gas dari hasil torefaksi dimanfaatkan untuk menentukan massa komponen gas dan kandungan energy yang dapat dimanfaatkan dari gas torefaksi.

Pengujian emisi pada produk torefaksi tandan kosong kelapa sawit dilakukan untuk melihat kandungan $\mathrm{CO}, \mathrm{HC}, \mathrm{NOX}, \mathrm{CO}_{2}$, dan $\mathrm{O}_{2}$ pada produk torefaksi tandan kosong kelapa sawit ketika dilakukan pembakaran. Selain itu pengujian emisi ini dilakukan untuk menentukan kepatuhan terkait undang undang polusi yang dikeluarkan oleh Kementrian Lingkungan Hidup Indonesia yang di keluarkan oleh Mentri Lingkungan Republik Indonesia (KEP13/MENLH/3/1995) mengenai kualitas udara. Adapun hasil pengujian emisi dapat dilihat pada Tabel 3.

Dari pengujian yang telah dilakukan diketahui bahwa pada tandan kosong kelapa sawit sebelum dilakukan torefaksi mendapatkan hasil untuk $\mathrm{CO}$ sebesar $10.00 \%, \mathrm{O}_{2}$ sebesar $17.34 \%$, hal ini dapat dilihat dari gambar $\mathrm{CO}_{2}$ sebesar $19.01 \%$, $\mathrm{HC}$ sebesar $15.21 \%$ dan NOx sebesar $61.07 \mathrm{ppm}$. Pada produk torefaksi limbah tandan kosong kelapa sawit yang telah di torefaksi dengan temperatur torefaksi $200^{\circ} \mathrm{C}$ didapatkan hasil pengujian untuk $\mathrm{CO}$ sebesar $9.12 \%, \mathrm{O}_{2}$ sebesar $18.53 \% \mathrm{CO}_{2}$ sebesar $19.01 \%$, $\mathrm{HC}$ sebesar $14.34 \%$ dan Nox sebesar $59.22 \mathrm{ppm}$.
Tabel 3. Hasil pengujian emisi gas buang

\begin{tabular}{crrrrr}
\hline PRODUK & $\mathrm{CO}(\%)$ & $\mathrm{O}_{2}(\%)$ & $\begin{array}{l}\mathrm{CO}_{2} \\
(\%)\end{array}$ & $\begin{array}{c}\mathrm{HC} \\
(\mathrm{PPM})\end{array}$ & $\begin{array}{c}\text { Nox } \\
(\text { p pm) }\end{array}$ \\
\hline M & 10.00 & 17.34 & 19.01 & 15.21 & 61.07 \\
\hline A & 9.12 & 18.54 & 17.94 & 14.34 & 59.22 \\
B & 9.01 & 19.83 & 17.11 & 9.51 & 58.03 \\
C & 5.75 & 19.22 & 12.79 & 2.22 & 57.31 \\
\hline D & 5.02 & 19.29 & 8.27 & 0.20 & 55.90 \\
E & 4.31 & 20.43 & 6.26 & 0.14 & 41.31 \\
\hline
\end{tabular}

Pada temperatur torefaksi $225{ }^{\circ} \mathrm{C}$ didapatkan hasil pengujian emisi untuk $\mathrm{CO}$ sebesar $9.01 \%$, $\mathrm{O}_{2}$ sebesar $19.83 \%, \mathrm{CO}_{2}$ sebesar $17.11 \%$, HC sebesar $9.51 \%$ dan Nox sebesar 58.03 ppm. Pada temperatur torefaksi $250^{\circ} \mathrm{C}$ didapatkan nilai $\mathrm{CO}$ sebesar $6.75 \%, \mathrm{O}_{2}$ sebesar $19.22 \%, \mathrm{CO}_{2}$ sebesar $12.79 \%$, HC sebesar $2.22 \%$ dan Nox sebesar $57.31 \mathrm{ppm}$. Pada temperatur torefaksi $275{ }^{\circ} \mathrm{C}$ didapatkan hasil pengujian $\mathrm{CO}$ sebesar $6.02 \%, \mathrm{O}_{2}$ sebesar $19.29 \%$, CO2 sebesar $8.27 \%$, HC sebesar $0.20 \%$ dan Nox sebesar 55.90 ppm. Pada temperatur torefaksi $300{ }^{\circ} \mathrm{C}$ didapatkan hasil pengujian emisi produk torefaksi limbah tandan kosong kelapa sawit yaitu untuk $\mathrm{CO}$ sebesar $4.31 \%, \mathrm{O}_{2}$ sebesar $20.43 \%, \mathrm{CO}_{2}$ sebesar $6.26 \%$, HC sebesar $0.14 \%$, dan Nox sebesar $41.31 \mathrm{ppm}$.

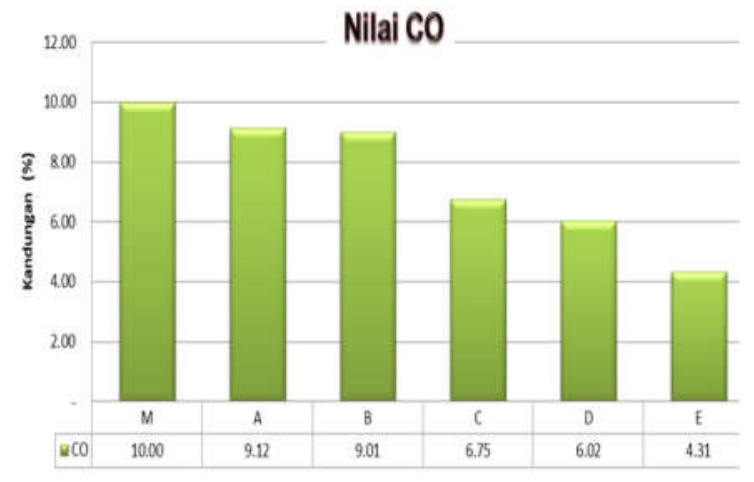

Gambar 5. Nilai CO

Analisis pada emisi $\mathrm{CO}$ atau gas karbon monoksida terbentuk pada pembakaran tidak sempurna, pada pembakaran produk torefaksi tandan kosong kelapa sawit, Kadar CO tertinggi terdapat pada tandan kosong kelapa sawit yang belum di torefaksi sebesar $10.00 \%$, hal ini disebabkan karena tandan kosong kelapa sawit sebelum di torefaksi memiliki fixed karbon yang paling rendah yaitu $10.80 \%$. Memiliki daya serap air yang sangat besar hal ini dapat dilihat pada saat melakukan pengujian hidrophobik, selain itu $\mathrm{O}_{2}$ yang dihasilkan juga paling sedikit yaitu $17.34 \%$, hal ini dapat menghambat 
terjadinya pembakaran sempurna dan menghasilkan gas $\mathrm{CO}$.

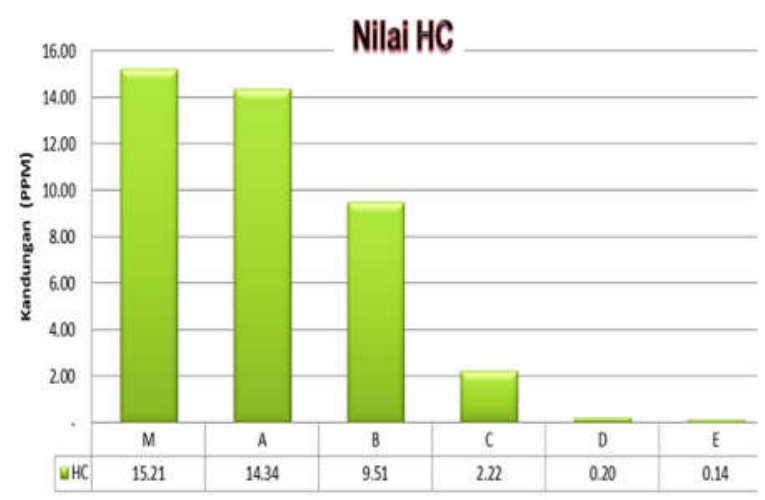

Gambar 5. Nilai HC

Nilai hidro karbon (HC) paling rendah adalah pada temperatur $300{ }^{\circ} \mathrm{C}$ yaitu sebesar $0.14 \%$ hal ini disebabkan karena pada temperature $300{ }^{\circ} \mathrm{C}$ produk torefaksi tandan kosong kelapa sawit terjadi pembakaran yang lebih baik dibandingkan sampel lainya, dapat dilihat dari O2 yang dihasilkan pada saat pembakaran dan dilakukan pengujian emisi lebih besar disbanding lainya yaitu $20.43 \%$ dan memiliki ash sebesar $9.0 \%$. Hal ini menjadikan temperatur $300{ }^{\circ} \mathrm{C}$ menjadi produk yang pembakaranya sempurna.

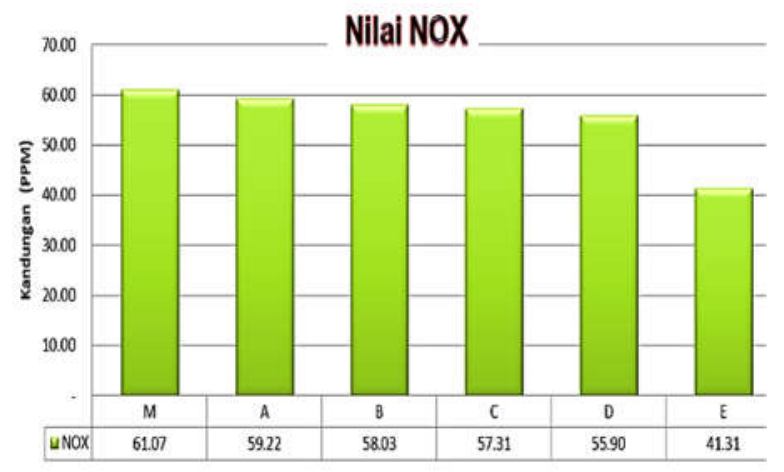

Gambar 6. Kandungan $\mathrm{NO}_{\mathrm{x}}$

Pada penelitian ini yang dilakukan menggunakan limbah tandan kosong kelapa sawit mendapatkan hasil NOx pada sampel mentah mendapatkan nilai terbesar yaitu $61.07 \mathrm{ppm}$, hal ini diakibatkan karena oksigen yang keluar pada saat pengujian terlalu sedikit

\section{KESIMPULAN}

Hasil pengujian proksimat menunjukan bahwa semakin tinggi kandungan fixed carbon akan meningkatkan nilai kalor dari produk padatan hasil torefaksi, Hasil pengujian nilai HHV terhadap produk padatan hasil torefaksi menunjukan bahwa nilai kalor produk padatan hasil torefaksi tandan kosong kelapa sawit berkisar antara 16357.23 - 21083.98 kJ. Dengan nilai kalor paling tinggi terdapat pada temperatur $275{ }^{\circ} \mathrm{C}$ yaitu sebesar $21083.98 \mathrm{~kJ}$. nilai LHV terhadap produk padatan hasil torefaksi menunjukan bahwa nilai kalor produk padatan hasil torefaksi tandan kosong kelapa sawit berkisar antara 15489.16 - 20029.01 kJ. Nilai kalor paling tinggi terdapat pada temperatur $275^{\circ} \mathrm{C}$ yaitu sebesar $21083.98 \mathrm{KJ}$, setara dengan batubara subbituminous $\mathrm{C}$ yang memiliki nilai kalor sebesar 19300 - $2100 \mathrm{~kJ}$, Hasil pengujian hydrophobic semakin meningkatnya temperature torefaksi tandan kosong kelapa sawit maka semakin kecil daya serap terhadap air pada produk torefaksi biomassa tandan kosong kelapa sawit, Hasil pengujian emisi pada biomassa tandan kosong kelapa sawit semakin meningkatnya temperature pada proses torefaksi maka produk tandan kosong kelapa sawit semakin mempunyai emisi yang baik hal ini bisa di lihat pada $\mathrm{CO}$ dan $\mathrm{Hc}$ yang nilainya semakin mengecil.

\section{DAfTAR PUSTAKa}

[1] Amrul. 2014. Pemanfaatan Sampah Menjadi Bahan Bakar Padat Setara Batubara Melalui Proses Torefaksi. Disertasi Institut Teknologi Bandung. Bandung.

[2] Basu Pabir. 2013. Biomass Gasification, Pyrolysis, and Torrefaction: Practical Design and Theory, Second Edition. Elsevier, Oxford, UK.

[3] Basu Pabir dan Dhungana A. 2013. An Investigation Into the Effect of Biomass Particle Size on its Torrefaction. Chem. Eng.

[4] Badan Pusat Statistik. 2019. Buku Informasi Statistik. Jakarta Badan Pusat Statistik. (bps.go.id)

[5] Bergman P.C.A., A.R. Boersma, J.H.A. Kiel, M.J. Prins, K.J. Ptasinski dan F.J.J.G. Jansen. 2005. Torrified Biomass for Entrained-Flow Gasification of Biomass. Report ECN-C-05-026.

[6] BPPT. 2017. Outlook Energy Indonesia 2017; Inisiatif Pengembangan Teknologi Bersih. Jakarta.

[7] Dengyu Chen, Anjiang Gao, Zhongqing Ma, Dayi Fei, Yu Chang, Chao Shen. 2017. In-depth study of rice husk torrefaction: Characterization of solid, liquid and gaseous products, oxygen migration and energy yield. Bioresource Technology. China

[8] Outlook Energy Indonesia. 2015, Jakarta, Dewan Energy Nasional 
[9] Tumuluru jaya Shankar, J Richard Hess, Shahab Sokhansanj, Christopher T Wright. 2011. A review on biomass torrefaction process and product properties for energy applications. Industrial Biotechnology.

\section{Biodata Penulis}

Retno Wahyudi, lahir di Wonodadi, Kecamatan Gadingrejo, Lampung 1 Maret 1993. Lulus di Universitas Negeri Padang pada jurusan Pendidikan Teknik Otomotif pada tahun 2015, pada tahun 2017 menjadi mahasiswa Magister Teknik Mesin Universitas Lampung, dengan Kosentrasi Konversi Energi sampai sekarang.

Amrul, lahir di Payakumbuh, 31 Maret 1971. Sarjana Teknik Mesin FT Unand 1997. Tahun 2001 memperoleh gelar Magister Teknik, dan tahun 2014 menyelesaikan program Doktor, keduanya di jurusan Teknik Mesin, Institut Teknologi Bandung. Bidang konsentrasi Konversi Energi. Staf pengajar di Jurusan Teknik Mesin, Fakultas Teknik UNILA, sejak tahun 1999 - sekarang.

Muhammad Irsyad lahir di Tanjung Bonai, Sumatera Barat, 14 Desember 1971. Sarjana Teknik Mesin FT Unand 1997. Tahun 2002 memperoleh gelar Magister Teknik di Universitas Gadjah Mada, dan tahun 2018 menyelesaikan program Doktor di Institut Teknologi Bandaung. Bidang konsentrasi Konversi Energi (penyimpanan energi thermal). Staf pengajar di Jurusan Teknik Mesin, Fakultas Teknik UNILA dari tahun 2000 - sekarang. 